\title{
Pojetí dějin, civilizací a politické současnosti Íránu u Mohammada Chátamího*
}

\author{
KAREL Č́rRÝ** \\ Mohammad Khatami's Concept of History, Civilisation and Contemporary Politics \\ of Iran
}

\begin{abstract}
Study focuses on cyclic concept of social change and specific notion of civilizations of Shia Iranian scholar and former president (1997-2005) Mohammad Khatami. In this philosophical framework, he deals with contemporary hot issues of post-cold war world, especially with dialogue among civilizations and with development of Iranian polity and society which tries to make a creative synthesis of the West and the East and create its own civic society and form of democracy as a result. This concept is seen in the context of deep and more than real ongoing internal conflicts between two competing forms of Shia political Islam after the Islamic revolution (1979). It focuses especially on the intra-sub-civilization clash between Khatami and so far dominant Khomeini version of political Islam and modernity. Not only Khatami but as well Karl Popper is invited to critically address the issue of Khomeini Shia historicism. At the end, the study compares Khatami with selected relevant leading Western scholars: Shmuel Eisenstadt, Amitai Etzioni, Samuel Huntington, and Francis Fukuyama.
\end{abstract}

Key words: Khatami, Khomeini, Eisenstadt, Eztioni, civilizations, multiple modernities, Shia political Islam, East and West

\section{„Vzájemně propojené zdroje íránské identity \\ - nacionalismus, islám a westernizace \\ - zůstávaji problematickou směsí."}

\section{Ideové tábory a spor uvnitř íránského revolučního režimu a perské sub-civilizace} Pokrokový šíitský ajatoláh a exprezident Íránské islámské republiky (1997-2005) Mohammad Chátamí $\left({ }^{*} 1942\right)$ v západním světě vyvolal rozruch svou inaugurační řečí, ve které nepranýřoval „Velkého Satana“ (tj. USA) ani Izrael, ale volal po dialogu civilizací, aby poté na televizní stanici CNN šokoval svým prohlášením, že si „Západ i Spojené státy zaslouží respekt“ [Esposito 2003: 137]. Chátamího zvolení představovalo největší íránskou vnitropolitickou událost od revolučního roku 1979, došlo ke snaze liberalizovat domácí poměry² a k opuštění zahraničně-politické doktríny „vývozu islámské revoluce“ ve prospěch pragmatické strategie „snižování napětí“ a „dialogu civilizací“ [Gombár

* $\quad$ Studie vznikla s podporou GA UK č. 9165/2009, jež se zabývá studiem faktorů vzestupu islamistických hnutí v regionu Blízkého východu. Inspirací k jejímu sepsání byla také autorova měsíční cesta po Íránu v roce 2007.

** Mgr. Karel Černý, Katedra sociologie Filozofické fakulty Univerzity Karlovy, Náměstí Jana Palacha 2, 116 38, Praha 1. E-mail: karlos.cernoch@post.cz

1 Sariolghalam [2008] vidí zdroje identity jako nekompatibilní, jako příčinu politických dilemat a paradoxů.

2 Pokus o „reformy v rámci systému“ je přirovnáván k perestrojce v Sovětském svazu nebo Pražskému jaru v Československu, Chátamí potom ke Gorbačovovi. V tomto kontextu je nutné vidět Chátamího dílo také jako propagaci občanské společnosti [Gombár 2001]. 
2001]. Dủležitost posledních parlamentních a prezidentských voleb $(2008,2009)$ je nutné vidět $\mathrm{v}$ kontextu měnících se mocenských konstelací a očekávaných změn na nejvýznamnějším postu v zemi, jímž je nejvyšší vůdce (rahbar). Jedním z nejvážnějších kandidátů na tuto pozici je právě Mohammad Chátamí [Nafisi 2007].

V Íránu lze zjednodušeně identifikovat dva protichůdné ideové tábory: internacionalisty a revolucionáře. Přitom Mohammad Chátamí s určitými výhradami spadá mezi internacionalisty, kteří požadují otevření země mezinárodním vlivům po vzoru Číny, Turecka či Malajsie. Zároveň plédují za aktivní zapojení do mezinárodního obchodu, tržní konkurence a ideové výměny. Zasazují se rovněž za vytvoření globálního systému vzájemné závislosti (interdependence), v němž vidí základ bezpečnosti, suverenity a blahobytu. Oproti tomu revolucionáři se staví za izolaci země od Spojenými státy vedeného mezinárodního systému, jenž je podle nich založen na útlaku, tajném spiknutí kapitalistů a snaze zničit islám. Ideálem je pevně svázaná a okolo dogmatického výkladu islámu sjednocená země jako záruka bezpečnosti a zajištění suverenity v okolním nepřátelském světě. Západ je pak v duchu okcidentalismu viděn jako koncentrované zlo a protipól idealizovaného islámského státu [Sariolghalam 2008; Buruma-Margalit 2005].

O tom, že v mocenské elitě převládá tábor revolucionářů s až paranoidním a nedůvěřivým pohledem na vnější svět, se lze přesvědčit prostřednictvím analýzy učebnic [Starrett-Doumato 2007]. Tato optika je v případě šíitského Íránu ještě umocněna sebepojetím chronicky pronásledovaných, kteří trpí za to, že ve vedení muslimské obce uznávají „rod Prorokova domu“, tedy imáma Alího a jeho potomky až do dvanáctého kolene v podobě skrývajícího se Mahdího [Kropáček 1996; Curkal 2007]. S bohatými odkazy na tragickou zkušenost s evropským imperialismem a následným vměšováním Izraele (Mossad) a Američanů (do roku 1979) tak učebnice podrobně líčí Írán jako ohrožovanou zemi v permanentním obležení [Freedom House 2008; CMIP 2007]. ${ }^{3}$

Ačkoliv je obtížné vměstnat ideové tábory šíitského politického islámu do západních politologických kategorií [Bumbálek 2007], uvedená typologie neodpovídá zjednodušujícím představám přeceňujícím roli dogmatických kleriků a podceňujícím „negativní“ roli technokratů s technickým nebo přírodovědným vzděláním západního typu. Duchovní jsou spíše apolitičtí, otevřeni diskuzi a rozdílným pohledům. Oproti tomu vstup „inženýrů“ do politiky - nejznámějším je prezident Ahmadínežád, ${ }^{4}$ prokázal regionu medvědí

3 Studie Institute for Monitoring Peace and Cultural Tolerance in School Education (dř́ve CMIP) předkládá obsahovou analýzu 95 íránských učebnic všech předmětů (od fársí a náboženství až po dějepis a matematiku v celkovém rozsahu 11 tisíc stran) používaných na základních a středních školách ve školním roce 2006/2007.

Nikoliv náhodou je moderní historie a „mezinárodní neřád“ v podání íránských učebnic viděn podobně jako ho popisují západní kritici globalizace a zahraniční politiky USA. V učebnicích se lze setkat s přímými odkazy například na díla Noama Chomského. Na Blízkém východě rezonuje hlavně jeho př́močará a tvrdá kritika zahraniční politiky USA. Chomsky ukazuje, že oficiální eufemismy typu „nátlaková diplomacie“ č̌i „válčení nízké intenzity“ ve skutečnosti halí nehezké akty, jež lze souhrnně označit za státní terorismus páchaný USA po celém světě, kde rozsévají strach a zlobu. To se pak čas od času obrací proti USA. USA navíc podporují tyrany celého světa, přičemž jim dodávají zbraně určené k potlačení opozice a terorizování civilistů (Saúdská Arábie, Kuvajt, Egypt, Maroko, Alžírsko, Pákistán, Turecko) [srov. Chomsky 2003].

4 Člen Islámské společnosti inženýrů (technokratické politické uskupení snažící se zabránit pronikání západní kultury, vzdělávat v oblasti náboženství, vědy, techniky a politiky). Doma politiku zakládá na dělení ropných zisků zohledňující potřeby chudých a boji s korupcí. Je silně věříím a konzervativním asketou [Cvrkal 2007]. 
službu. Jakožto náboženští samouci mají tendenci zastávat rituální, přísně ortodoxní a dogmatický směr islámu. Jelikož jsou jejich znalosti chabé a útržkovité, svůj světový názor zakládají na sérii dogmaticky chápaných pouček, které nejsou připraveni zpochybňovat ani flexibilně interpretovat. Právě „inženýři“ “ ale zastávají klíčové pozice ve vládě a státním aparátu [Sariolghalam 2008; Kepel 1996; Roy 1992; Dekmejian 1995].

Podobně nepřesné je na Západě rozširrené ztotožňování internacionalistů a reformistů s odpůrci náboženského režimu. Ti nezpochybňují islámský charakter země, jen nesouhlasí s interpretací islámu v podání současné moci, přičemž islám podle nich neznamená agresivní rétoriku a konfrontaci se světem, policejní režim, cenzuru a podřadné postavení žen. Demokracii a lidská práva pak odvozují z islámu, nechystají se zcela aplikovat demokracii západního typu. Spory Mohammada Chátamího a ajatoláha Alí Chameneího přesně vystihují tento konflikt [Mooddel 2006; Tureček 2007 a 2009].

\section{Cyklické, nebo lineární pojetí dějin?}

S koncem studené války a zhroucením bipolarity Chátamí nabízí svou obecnou filozofii dějin, v jejímž kontextu diagnostikuje současnou krizi islámského světa a problematický vztah se Západem. Za dvě největší výzvy 21. století v duchu „kosmopolitnějších“ internacionalistů přitom pokládá: za prvé nápravu deformovaného vztahu člověka k př́rodě chápané instrumentálně jako rezervoár surovin, určený pro exploataci, přitom tento pokřivený vztah se poté přenáší i na vztahy mezi lidmi, za druhé jako nápravu narušených vztahů a zabránění konfliktům mezi světovými civilizacemi. Řešení Chatámí vidí hlavně v mezicivilizačním dialogu jako základu nového paradigmatu mezinárodní politiky, dále v rozvoji islámské občanské společnosti a kritické sebereflexi Západu a světa islámu [Chátamí 2001].

Každá civilizace podle něj prochází cyklem svého zrodu, vzestupu a postupné stagnace ústící v nezadržitelný zánik. Přitom za „motor“ běžící v „,zákulisí“ cyklického chodu dějin pokládá Chátamí „dynamiku lidské přirozenosti“. Jde o dvě základní antropologické konstanty univerzálně platné pro lidi všech historických období, kulturních okruhů a geografických regionů. Za prvé o zvědavost, touhu po poznání a potřebu pochopit svět, kdy odpovědi na tyto otázky vedou k pokládání a vznikání otázek nových. Za druhé se prosazuje touha po uspokojování materiálních potřeb a požadavků, přičemž naplnění potřeb postupně ústí ve vznik potřeb zcela nových, dosud nepoznaných. Pokud se civilizaci daří uspokojivě reagovat na stále nové duchovni $i$ materiální potřeby, případně je i určitým směrem kultivovat a usměrňovat, pak vzkvétá. $V$ opačném př́padě přestává být pro zúčastněné atraktivní a dochází k úpadku [Chátamí 2001: 10, 66-68]. ${ }^{5}$

Civilizace však autor nechápe jako uzavřené a do sebe zahleděné entity, které by si vystačily jen samy se sebou: „Nové civilizace nejsou nikdy zcela nové (...) živí se prací předchozích civilizací, stráví to, co vyhovuje jejich potřebám, a obejdou se bez toho, co nepotřebují“, případně se i vyhnou jejich omylům a „slepým uličkám“ [tamtéž: 66, 74]. Stejně tak dochází ke komunikaci civilizací existujících ve stejné době. Civilizace jsou tedy otevřené a působí ve vzájemné inspirativní interakci, a jedině tak může docházet $\mathrm{k}$ dlouhodobě zdravému vývoji.

5 Jde tedy o nemateriální i materiální potřeby, jež lze snad převést do podoby kultury duchovní a materiální. Antropologická východiska o povaze člověka tvoří základ řady teorií (cyklických i lineárních) sociální změny. 
Chátamího pojetí dějin sice pracuje s představou cyklického vývoje a střídání jednotlivých civilizací, avšak za tímto pomíjivým děním se skrývá lineární, kumulativní a ireverzibilní pokrok lidské racionality a vědění. Jednotlivé civilizace tak vystupují jako atleti v pomyslném štafetovém běhu řady civilizací předávajících $\mathrm{v}$ příhodný okamžik štafetový kolík v podobě reprodukovaného a dále obohacovaného poznání z rukou civilizací zanikajících do rukou nově nastupujících. ${ }^{6}$

\section{Islám a Západ. Krize provázející vznik a zánik civilizací}

Úpadek kdysi mocné perské civilizace způsobilo podle Chátamího přílišné zahledění do sebe a absence otázek, jež vedly k absenci myšlení a všeobecné stagnaci. Významnou roli sehrála rovněž stále méně kreativní a dogmatičtější interpretace islámu, která se postupně prosadila. ${ }^{7}$ Náboženské dogmatiky a fanatiky Chátamí pokládá za nebezpečnější než světské liberály a sekularisty. Na lid totiž mají podle něj větší vliv než nesrozumitelní a př́liš „abstraktní“ intelektuálové. Dogmatikům vyčítá, že přisuzují „svatost a věčnost ve skutečnosti omezeným a neúplným lidských interpretacím víry“ a zároveň emoce a víru nadřazují nad rozum, ačkoliv jsou v životě věřícího obě složky nepostradatelné a rovnocenné [tamtéž: 78]. Má-li tedy být civilizace stavící na náboženství svěží a vitální, pojetí náboženství musí být dynamické, nikoliv těžkopádné a statické: „Víra musí téci jako řeka, aby existovala. Je málo naděje ve stagnující bažině. Víra může přinést plody mravnosti a míru, bude-li neustále téci [tamtéž: 21].“

Naproti tomu největší devizou Západu je dle autora kritický přístup a permanentní sebereflexe. Chátamí mimo jiné zdůrazňuje „západní“ hodnoty svobody a tolerance. Domnívá se ale, že zatímco krize dnešního islámského světa (především způsobená íránskou revolucí) je krizí zrodu nové a nastupující civilizace, jejími porodními bolestmi. „Západní civilizace je obnošená a senilní“, její chronické těžkosti - např. krize rodiny, vztah k přírodě, krize vědecké etiky, signalizují brzký pád. Chátamí připomíná, že Západ dominuje již déle než bylo u většiny historických civilizací obvyklé. Nezbývá mu pak nic jiného než jít cestou započatou nejpozději v 19. století, kdy své vnitřní problémy a rozpory začal řešit na úkor okolí, a to jak sociálního, tak i přírodního: kolonialismus provázený nejrozsáhlejším porušováním lidských práv v dějinách, rozpoutání světových válek, neokolonialismus a ekologická krize [tamtéž: 2, 69]. ${ }^{8}$

\section{Jak vytvořit vzkvétající muslimskou společnost budoucnosti?}

Co normativního Chátamí navrhuje? Nejprve má jít o kritickou sebereflexi ústící v jakousi inventuru či revizi pojetí islámu a kultury, což má napomoci pochopení vlastní minulosti a identity, dále posloužit jako zdroj nedostávající se cti a hrdosti a konečně pak vytvořit základ pro hledání cesty do budoucnosti, nikoliv návratu do středověku. Stručně řečeno, jde o to pochopit kdo jsme, odkud pocházíme, jaké máme silné a slabé stránky a kam směřujeme [tamtéž: 11].

6 Chátamí zdůrazňuje roli civilizace islámské jako „mostu“ mezi starověkými civilizacemi - nejen řeckou a římskou, a Západem. Vědění i hodnotu tolerance dnes Západ paradoxně znovu „nabízí“ a připomíná islámu.

7 Tato diagnóza úpadku civilizace připomíná rozbor pádu Osmanské říše v podání orientalisty Bernarda Lewise [2003].

8 Na návrh Î́ránu schválila Organizace spojených národů (OSN) rok 2001 jako „rok dialogu civilizací“. To je vzhledem k útokům z 11. září a válce s terorismem ironické, nebot rok 2001 se do dějin zapíše spíše jako období „střetu civilizací“ a „obav z islámu“. 
Na tomto místě Chátamí rozlišuje mezi civilizací a kulturou a jim nadřazeným islámským náboženstvím. Jestliže jsou civilizace a kultury pomíjivé, víra a náboženství jsou věčné; proměňují se jen výklady, projevy a zpưsoby prožívání. V př́ípadě staré slavné islámské civilizace proto zanikla jen určitá interpretace islámu. Náboženství je však natolik dynamické a vitální, že v sobě nese prakticky nevyčerpatelný potenciál poskytovat odpovědi na jakékoliv otázky a potřeby lidí v různých epochách. Odtud pramení autorův optimismus, který zdůrazňuje, že se po íránské revoluci (1979) rodí nová a perspektivní civilizace [tamtéž: 21, 70,74]. Takto vybavena sebereflexí má být islámská civilizace schopna moudře a tvůrčím způsobem využít všech úspěchů dnes dominujícího Západu, a to tak, aby nedošlo jen k bezduché nápodobě, ale byla zachována cenná kulturní a sociální specifika: „S otevřenou náručí musíme mít prospěch z pozitivních aspektů jiných civilizací a kultur [tamtéž: 4]. "Zde přichází ke slovu Chátamím tolik vzývaný mezicivilizační dialog, přesněji dialog mezi Západem a Východem, v tomto pojetí zprostředkovaný hlavně intelektuály. Společné „mluvení a naslouchání“ by podle něj mělo vyústit ve vyváženou syntézu k duchovnosti a kolektivismu tíhnoucímu Východu a k racionalitě a individualismu se upínajícímu Západu. ${ }^{9}$ Jestliže mnozí vidí rozpor a nekompatibilitu mezi rozumem a vírou (svobodou a vírou; kolektivismem a individualismem; povinností a svobodou), autor se domnívá, že se naopak vzájemně doplňují a jen jejich „koncert“ vede k osobnostní a společenské harmonii. ${ }^{10}$

Islámská civilizace však nebude vzkvétat bez rozvoje islámské občanské společnosti a demokracie. Islám je dle autora kompatibilní s demokratickými principy a hodnotami svobody nebo tolerance a navíc Bůh oprávnil lid určovat svůj osud. Občanskou společností Chátamí nechápe její západní verzi navazující na řeckou polis, nýbrž ji odvozuje z původní Prorokovy obce věřících: „Občané islámské občanské společnosti se těší právu určovat svůj vlastní osud, dohlížet na způsob vládnutí a nutit vládu předkládat účty. (...) Vláda v takové společnosti slouží lidu a není jeho pánem.“ Autor nezapomíná ani na práva menšin, bez nichž demokracii hrozí, že se promění v tyranii většiny [tamtéž: 12].

\section{Mezinárodní vztahy mezi střetem a dialogem}

Chátamí vidí disproporci „mezi naší civilizací a naším současným stavem“ [tamtéž: 2], ještě větší propast mezi ideálem a skutečností ale spatřuje v oblasti mezinárodních vztahů. Zde jsou totiž mezilidské vztahy založeny primárně na moci a silnější stranou vnucovaných pravidlech a zákonech. Zdánlivý mír je pak jen mírem hegemonistickým a dlouhodobě neudržitelným. Oproti tomu mezinárodní vztahy založené na racionalitě a dialogu produkují mír dlouhodobě udržitelný a umožňují společně řešit hlavní výzvy 21. století.

9 V islámské teorii vzdělávání se zdůrazňuje, že vědění pochází z harmonického a komplexního rozvoje celé osobnosti - fyzické, intelektuální, morální a duchovní dimenze člověka [srv. Daun-Arjmand 2005]. Zde je zřetelný soulad s původní antickou koncepcí kalokagathia, přičemž v tomto pojetí člověka Chátamí nenachází nutnou rozpolcenost člověka, kterou často zdůrazňuje evropské myšlení.

10 Autor uvažuje ve stereotypních binárních opozicích „Východ vs. Západ“ kritizovaných Edwardem Saidem [2008]. Nejde však o černo-bílé schéma stavící iracionální, zaostalý, barbarský a nebezpečný Východ do protikladu s racionálním, vyspělým a civilizovaným Západem. Oběma entitám dnes Chátamí shodně přičítá silné i slabé stránky a chápe je jako rovnocenné. Peršané samotní [Rypka 1946] disponují vlastním binárním dělením světa na dva protichůdné a konfliktní celky - Írán (dobro, „my“) vs. Túrán (zlo, „oni“), představené ve vlasteneckém heroickém eposu Kniha králů (10. století n. 1.), popisujícím dějiny od stvoření prvního člověka po nástup islámu. 
Hegemonem po zhroucení bipolarity se staly Spojené státy americké, které dominují unipolárnímu uspořádání mezinárodních vtahů a velmi brání jakýmkoliv snahám ostatních o dosažení nezávislosti a suverenity. Hlavním cílem USA je totiž „vládnout všem částem světa“ a kontrolovat strategické přírodní zdroje: „Od dávných dob koloniální mocnosti ospravedlňovaly zabírání cizí půdy a znásilňování jiných národů jejich rozvojem a civilizováním [tamtéž: 71].“ Dnes tak Spojeným státům k legitimizaci násilí slouží údajná obrana lidských práv a demokracie. Autor se zároveň obává dnešní zahraniční politiky Západu: „Náš boj se Západem dosahuje významu života a smrti [tamtéž: 71]. “ Dalším problémem je dosud přetrvávající a podporované paradigma studené války. To vychází z existence hrozby západní civilizaci, čerpá z představ skutečného či jen vykonstruovaného nepř́tele. Pokud za bipolarity hrál roli strašáka Sovětský svaz, dnes se hledá a také nachází nebezpečí v islámu [tamtéž: 13-17].

Jako protilék konfliktního vývoje světové politiky Chátamí nabízí nové paradigma mezinárodních vztahů postavené na dialogu civilizací, kultur a náboženství. Zprostředkující roli zde mají sehrát státníci a myslitelé, kteří komunikují jak se svými rovnocennými partnery z jiných civilizací, tak s elitami a veřejností uvnitř civilizací vlastních. Intenzivní dialog, založený na rozhovoru, jakož i stejně naslouchání, má vést ke vzájemné obeznámenosti a porozumění, ke snížení zbytečných oboustranných obav, zneutralizování očerňování islámu a k posílení důvěry v mezinárodních vztazích jako hlavního předpokladu míru a spolupráce. ${ }^{11}$

\section{Druhá tvář šíitské sociální filozofie a cesta k revoluci: Imám Chomejní}

Tábor reformistů a internacionalistů, za jejichž ikonu lze Chátamího označit, soupeří s konzervativci a revolucionáři, jejichž duchovním otcem je Chomejní. Oba ajatoláhové předkládají dvě vzájemně konfliktní polohy šíitského politického islámu, které se shodnou jen na obecné zásadě určité role islámu v politice [Richards - Waterbury 2008].

Jako konkurenční protipól koncepce islámské občanské společnosti a dialogu civilizací lze vidět Chomejního dílo Islámská vláda [Chomejní 2004]. ${ }^{12}$ Jde o nejkomplexnější spis o vládě šíitských duchovních v době skrytosti dvanáctého imáma, o jeden z hlavních ideových katalyzátorů revoluce (pašování a šíření za diktatury), hlavní inspiraci islamistů celého světa (vedle spisů Sajjid Qutba a Abú Aclá al-Mawdůdího) a základ současné íránské ústavy. Pojednává o situaci v předrevolučním Íránu, dále zdůvodňuje legitimitu a nutnost islámského státu, rozebírá roli duchovenstva v politice, konečně pak revoluční strategii svržení sekulární diktatury [Kepel 2002; Cvrkal 2007; Bumbálek 2007; Juergensmeyer 2008].

V okázalém přepychu žijící šáh podle Chomejního na zdroje bohatou zemi zruinoval, zadlužil a uvrhl do bídy. ${ }^{13}$ Rozdělil ji na chudé a bohaté, utlačované a utlačovatele, a přitom představoval na cizincích závislou loutku vykonávající politiku diktovanou

11 Kromě změny myšlení autor vybízí i ke změně reality mezinárodních vztahů od unipolarity k multipolaritě a k většímu vyvážení USA. Rozvoj světa islámu pak má přinést bezpečí a nezávislost na „politické, psychologické, kulturní a hospodářské nadvládě Západu“. Zde muslimy nabádá také k islámské jednotě [tamtéž: 73].

12 Hlavní kontury své politické teorie Chomejní načrtl již v práci Odhalení tajností z roku 1943 [Bumbálek 2007].

13 Rostoucí podíl ropných zisků byl investován do vybudování největší armády regionu [srv. Cvrkal 2007]. 
kolonialisty v čele s Američany. ${ }^{14}$ Podle něj se Spojené státy snaží rozdrobit jednotu islámského světa a v rozporu s islámskými principy si účtují většinu zisků z vytěžené ropy. Zástupy cizinců vyjmutých z právní jurisdikce země pak okázale ignorují místní zvyklosti: „Jak můžete mlčky a nečinně přihlížet tomu, jak si část zrádců, lichvářů a přisluhovačů s pomocí cizinců a silou bajonetů přivlastňuje bohatství a výsledky práce stamilionů muslimů a nedovolí, aby alespoň nepatrnou část měli pro vlastní potřebu [Chomejní 2004: 48]?“

Chomejní kritizuje nerovnosti a zdůrazňuje sociální senzibilitu islámu: „Slepí, němí a chromí jsou zanedbáni ve všech městech. Nikdo se nad nimi neslituje (...). Islám řeší problém chudoby. Tento problém v jeho programu stojí na prvním místě. (...) Jsme povinni podporovat utlačované a být nepřáteli utlačovatelů [tamtéž: 48, 114]. “ Chomejní kritizuje rovněž i nefunkčnost, pomalost, nespravedlnost a zkorumpovanost státní správy a soudnictví, rrídící se mechanicky a formálně převzatým belgickým a francouzským právem, ve kterém se běžný Íránec naprosto ztrácí. V anonymních bludištích nových byrokratických úřadů se dle autora prostý občan nedomůže svých práv. V kontrastu s tím Chomejní vyzdvihuje jednoduchost, transparentnost a spravedlnost osvědčeného soudnictví islámského. ${ }^{15}$

Odpudivá je dále podle něj snaha šáha vytěsnit islám a duchovní z politiky, vzájemně oddělit a odcizit kleriky a věřící a překroutit islám tak, aby sloužil moci a přišel o svůj sociálně-kritický a revoluční potenciál. Šáh a Američané se snaží rozvrátit islám, protože ten představuje jediné ohrožení a bariéru jejich mocenských a materiálních zájmů. Podle Chomejního si duchovní nemají nechat vnutit pasivní roli přisluhovačů moci, zabývajících se jen apolitickými a podružnými tématy typu „předpisy o menstruaci a šestinedělí“ či vztahem člověka a Boha po vzoru křestanství: „Oni touží po vaší ropě. Proti vaší modlitbě nic nemají [tamtéž: 36].“

\section{Kudy vede cesta do utopie?}

V této části textu Chomejní není až tak originální, spíše navazuje, radikalizuje a selektivně rozpracovává tradici šíitského politického myšlení. Rozkol muslimské obce záhy po smrti Proroka měl čistě politickou povahu - spor o nástupnictví. Za chalífát plédující sunnité byli názoru, že vedení osiřelých muslimů má být svěřováno na základě všeobecného konsenzu vůdci, který je tak jen „prvním mezi rovnými“. Oproti tomu šíity podporovaný imámát předpokládá, že před smrtí Prorok pověřil vedením obce Alího, svého bratrance, blízkého př́tele, jednoho z prvních muslimů a manžela své dcery Fátimy. Muslimy má proto dědičně vést „rod Prorokova domu“. Imámové z této linie jsou „Bohem správně vedení“ a setrvávají s ním v jakémsi mystickém vztahu podobném přátelství (wilája). Jsou sice smrtelní, nicméně bezchybní, čistí, moudří a téměř vševědoucí - úplní „duchovní ředitelé lidstva“. ${ }^{16}$ Zkrátka, jelikož si Bůh nepřeje pád lidstva do bezbřehé anarchie a příčí

14 Jde o údajné konspirační spiknutí Západu, Židů a křestanů [Chomejní 2004].

15 Úkony takového právního systému se mohou odbýt za pár minut třeba na nádvoří páteční mešity.

16 Líčení imámů jako historických osobností těmto superlativům neodpovídá. Striktně je hodnotí historik Jan Rypka [1947: 50], když komentuje éru šestého imáma Rizá, zavražděného v Mašhadu následovně: „, (...) byl to typický člen rodiny Prorokovy, která počínaje chalífou Alím až do dvanáctého a posledního imáma nepobrala mnoho ani z geniality Mohammedovy, ani z politické obratnosti, bystrozrakosti a bezohlednosti svých nepřátel, chalífủ umajjovských a abbásovských (...) samé faux-pas, jež dělali, a ustavičné sliby-chyby, kterými byli krmeni“. 
se mu také tyranie, dal muslimům spravedlivé vůdce v podobě imámů [Bumbálek 2007; srv. také Mooddel 2006; Kropáček 1996; Rypka 1947].

Co ale dělat po dobu odchodu dvanáctého imáma do okultace (roku 868), ze které se podle šíitských eschatologických vizí má vrátit až někdy před koncem věků. Kdo má v tomto provizorním mezidobí vládnout a suplovat řadu duchovních i politických funkcí (např. vedení páteční modlitby a džihádu, dělení kořisti, výběr a dělba daní, rozhodování soudů a trestání, výklad nejednoznačného islámského práva)? ${ }^{17}$ Raná šíitská doktrína dominující asi do 11. století tvrdila, že nikdo, což se ale záhy ukázalo jako nepraktické. Postupně se začal prosazovat a krystalizovat klasický šíitský koncept vykladačů práva (ulamá) jako zástupců skrytého imáma (Náib al-Ámm). Ti pak v průběhu dějin krok za krokem přebírají funkce imámů - nejprve v oblasti výkladu a aplikace práva a víry, poté ve sféře politiky [Bumbálek 2007].

Jestliže až do 16. století žili šíité jako menšina v rámci většinově sunnitských monarchií, nepotřebovali podrobně rozvíjet politickou teorii. Změnilo se to až za vlády perských dynastií, Safíjovců a Kádžárovců, kdy dochází k symbióze mocenské elity a ulamá, kteří mají dynastie legitimizovat $\mathrm{v}$ očích zbožné a již většinově šíitské populace. Typický projev tehdejší šíitské politické teorie představuje oficiální klerik Mírzá Abú-lQásim Qomí (zemřel roku 1816), jenž přichází s tím, že po dobu skrytosti dvanáctého imáma jeho moc přechází na dvě skupiny: na duchovní, kteří drží moc ve věcech náboženství, a světské vládce, jež se uplatňují v politice. Obě vzájemně závislé skupiny musí v tomto pojetí spolupracovat. Bez řádu prosazeného a vynucovaného státní mocí nelze zcela aplikovat islámské právo, bez vedení a usměrňování politické vlády duchovenstvem se pak samotná politická moc zvrtne v pouhou tyranii, kterou nebudou lidé následovat. Toto pojetí vlády dominovalo až do islámské revoluce. Určitý vrchol role duchovních v politice předrevolučního Íránu představovala ústavní revoluce v roce 1906, jež zaváděla instituci Náboženské rady, v níž mělo zasedat pět islámských právníků. V její pravomoci bylo posuzovat soulad parlamentem přijímaných zákonů s islámským právem a případné „Zmetky“ vracet poslancům k přepracování. Odtud vede relativně přímá cesta $\mathrm{k}$ Chomejního koncepci islámského státu a vlády duchovních [Bumbálek 2007; Cvrkal 2007]. ${ }^{18}$

Podle Chomejního [2004] je následně islám pevně spjat s politikou. Mohammed, první chalífové a všichni imámové ostatně v jedné osobě koncentrovali duchovní a politickou moc. Islám je komplexní a všeobjímající, nebot obsahuje i podrobné předpisy pro vedení války, mezinárodní vztahy, ekonomiku a vládu. Absolutistická nebo konstituční monarchie, ale také západní demokracie, jsou pak protivníky islámu. Zdrojem zákonů to-

17 Šíitské pojetí dějin rozlišuje malou a velkou okultaci. V prvním období (868-941) skrytý imám, jakožto jakýsi prostředník mezi Bohem a lidmi, s věřícími ze skrytosti komunikuje skrze čtyři po sobě jdoucí prostředníky. Tato vícenásobná zprostředkovanost končí, když se přerušuje kontakt mezi skrývajícím se imámem a šítskou obcí. Naplno se vynořuje otázka, kdo má vládnout namísto skrytého absentéra [Bumbálek 2007].

18 Porevolučně vypracovávaná ústava měla vycházela z konstituce z roku 1906. Duchovní měli podle ní opět pouze dohlížet na přijímané zákony. V Radě dohlížitelů mělo zasednout pět islámských právníků a šest právníků civilních, navíc mohli posuzovat soulad zákona s ústavou a islámským právem jen na něčí podnět, nikoliv tedy všechny zákony a ne z vlastní vůle. Ústava jasně hovořila o demokracii a občanských právech. Chomejní ji prvně takticky podpořil, po likvidaci sekulární opozice se však lidé v jeho okolí od této verze odklánějí ve prospěch islámského státu a větší role duchovních, což bylo schváleno i v referendu [Bumbálek 2007]. 
tiž nemůže být tyran ani lid. Zákony lidem jednou provždy seslal Bůh, nelze je autoritářsky měnit, ani o nich demokraticky hlasovat. Islámský stát je oproti tomu systémem, kde jsou vládci zavázáni dodržovat Boží zákon úplně stejně jako všichni ostatní: „Islámský stát je státem zákona. Vláda náleží jedině Bohu a zákon je Božím příkazem [tamtéž: 52].“

Podle této státoprávní teorie plyne nutnost zřídit stát $\mathrm{z}$ povinnosti muslimů, uvést Boží zákon do praxe. Samotná sepsaná sbírka zákonů v knihovně nebo pasivní recitování mezi čtyřmi stěnami samo o sobě nestačí, nutná je exekutivní moc, jež zákony každodenně implementuje a vymáhá. Stát musí dohlížet na normy a morálku, protože „lidé chybují, jsou nedokonalí a mají tendenci porušovat zákony a práva na úkor druhých “ [tamtéž: 49]. Navíc „neexistuje jiný prostředek k zabránění anarchie a zkažení společnosti“ [tamtéž: 39]. Bez státu také nelze organizovat společnou obranu proti nepříteli či přerozdělovat daně uložené islámem (podle logiky „každý př́ijem má i svůj výdaj“).

Klíčovou roli při budování a správě islámského státu mají hrát duchovní. Vládnout v období okultace dvanáctého imáma přitom není výsada, ale povinnost spočívající v ustavení práva a vymýcení bezpráví, v přikazování vhodného a zakazování zavrženíhodného, v každodenním rozlišováním mezi dobrem a zlem ve všech otázkách, a to na úrovni komunity i na celostátní úrovni. Adeptem na post nejvyššího vládce, jenž má úkoly analogické proroku Mohammedovi, je v Chomejního dikci jakýsi „král-filozof“. Jde o spravedlivého, moudrého a dokonalého znalce zákonů: „Je třeba vůdce, který uskutečňuje zákony a neprosazuje vlastní touhy a vášně, vůdce, pro něhož jsou si všichni lidé rovni před zákonem, vůdce, pro něhož mají všichni lidé stejné povinnosti a stejná práva, nikoho nezvýhodňuje a nediskriminuje [tamtéž: 124]. . ${ }^{19}$

\section{Revoluční náboj šíitského islámu, institucionální hybridizace a porevoluční vystřízlivění}

Íránská revoluce a zdejší islamistické zřízení podrobně navržené ajatoláhem Chomejním je často vykládáno - na Západě i samotnými revolucionáři - jako univerzální model, ke kterému vzhlížejí rovněž ostatní islamisté. Je však třeba poukázat na specifika šíitské větve islámu, $\mathrm{z}$ níž Chomejní čerpá a v jejímž kontextu k revoluci došlo, což také vysvětluje, proč se nakonec jinde revoluce nekonala.

Jestliže sunnité ve svém dějinném pesimismu pokládají za „zlatý věk“ éru Prorokovy obce v Mekce a Medině a vládu prvních čtyř „správně vedených“ chalífů, přičemž od té doby se věci spíše jen zhoršují, dějinně optimističtí šíité v duchu mesianistických představ čekají na návrat mesiáše v osobě skrývajícího se dvanáctého imáma. Ten je př́mým potomkem proroka Mohammeda a skutečným vůdcem všech muslimů, přičemž se má dle šíitských eschatologických vizí na zemi opět zjevit před koncem věků jako hrdinný vůdce sil dobra v jejich apokalyptickém střetu se silami zla. Po svém drtivém vítězství, kdy zatočí se všemi podobami špatnosti a nespravedlnosti, se opět a definitivně ujme vlády. Projekt spravedlivého islámského státu je předkládán jako nutný předpoklad jeho návratu ze skrytosti, nebo dokonce jako krok urychlující a usnadňující tento návrat, jako krok na cestě ke konci světových dějin. Právě charismatik Chomejní byl často viděn

19 Navýsost zajímavé a u nás neznámé jsou texty Michela Foucaulta, sympatizující s Chomejním a takto chápaným politickým islámem. A zejména aktuální diskuze na toto téma [např Afary - Anderson 2005]. 
jako dvanáctý imám (sám to ale nepotvrdil, ani nevyvrátil), což byl další katalyzátor mobilizace zbožného obyvatelstva.

V šíitském islámu je politika s vírou propojena snad ještě silněji než v sunnitském. Šía vznikla ze sporu o nástupnictví po smrti Proroka, kdy šíité tvrdí, že vůdci muslimů mají být mužští potomci Alího (imámové). Imámové tedy v jedné osobě koncentrují duchovní a politickou moc. Šíitští duchovní pak své ambice odvozují z faktu skrytosti dvanáctého imáma, za kterého musí někdo vládnout, což jim dává vyšší legitimitu ve srovnání s duchovními sunnitskými, jejichž legitimita se odvozuje jen z jejich erudice. Svou legitimitu mohou často odvozovat též z rodokmenu jdoucího k některému z imámů či př́mo k Mohammedovi (např. Chomejní rodokmen odvozoval od Proroka). Moc a nezávislost šíitského duchovenstva na státu se dále odvíjela od materiálního zajištění, pozemků, správy nadací a výběru daní. Taktéž vycházela z vnitřní ideové konsolidace symbolizované sjednocením tři právních škol v 18. století. Vedla tak k provázání ulamá a vytvoření částečné hierarchie nepatrně připomínající křest̉anskou církev. Oproti tomu sunnitské duchovenstvo takovouto ekonomickou nezávislostí nedisponuje, není organizováno na bázi čehokoliv připomínajícího církev a v čele politického islámu v sunnitském světě také vesměs dominantně nestojí (ačkoliv se i zde někdy hovoří o dualitě vůdcovství, např. v alžírské Frontě islámské spásy, FIS). V neposlední řadě také popularita duchovních čerpala z likvidace sekulární opozice tajnou službou SAVAK. Vedlo to k monopolizaci kritiky neoblíbeného režimu a následné exkluzivitě při organizování a reprezentování opozice. ${ }^{20}$

V šíitském islámu je také ukryt výrazný revoluční náboj a tradice odporu vůči „nelegitimním“ sunnitským vládcům a dynastiím. Snad nejvýrazněji se manifestuje svátkem ašúra (připomínajícím křestanské pašije), odkazujícím na mučednickou smrt imáma Hussaina u Karbalá a dále na kolektivní vinu řadových šíitů, kteří mu tehdy nepřispěchali na pomoc (odtud je odvozen rituál sebemrskání a sebezraňování). Není náhodou, že četné rebelie vznikly právě v tomto emocionálně rozjitřeném období plném morálních apelů, kdy byly připomínány analogie mezi současnými zkorumpovanými vládci a umajjovským chalífou Jazídem, jenž dal Hussaina zlikvidovat. Podobně odtud čerpá i šíitský kult mučednictví, který nabyl obřích rozměrů v irácko-íránské válce (1980-1988), avšak hrál roli také v revoluci [Kropáček 1996; Juergensmeyer 1994, 2008; Mooddel 2006; Kepel 2002; Zubaida 2009].

Univerzální aplikovatelnost a bezproblémovost Chomejního koncepce zpochybňuje rovněž realita porevolučního Íránu, např. sociální a ekonomická situace, omezíme se však na aspekty politické. Ačkoliv Chomejní tvrdí, že není zapotřebí, aby si lidé pro sebe vymýšleli pravidla a schvalovali zákony, protože v islámu je již vše dokonale promyšleno a předpřipraveno Bohem a jen se čeká na aplikaci, v praxi islámské republiky dochází k řadě zádrhelů. Íránci tak očividně nežijí v bezproblémové utopii [Richards - Waterbury 2008]. Jestliže Chomejní načrtl teokratický zposob vlády, realitě režimu odpovídá spíše pojem teokratická republika, která je jakýmsi hybridem kombinujícím existenci několika paralelních mocenských center a protichůdné principy parlamentní demokracie. Odkazuje se na suverenitu lidu, která má být vyvažována mocí duchoven-

20 Tento mechanismus je př́tomen v celém regionu Blízkého východu, jde tedy spíše o otázku míry represí. 
stva opírajícího se naopak o suverenitu Boha a o údajnou znalost jeho vůle [srv. Čejka 2009; Cvrkal 2007]. Samotná ústava tak představuje relativně vnitřně rozporný koncept, přičemž kombinuje demokratické prvky (volený prezident, vláda a parlament, institut referenda, jenž byl využit i k jednorázové legitimizaci vlády duchovních a primátu Boží vůle) a sekulární západní prvky, ačkoliv se režim snaží vymezovat protizápadně a zdůrazňovat domácí původ. (Koncepty dělby moci, suverenity lidu, národa, republiky či všeobecných voleb, jež islámské právo nezná a nelze z něj přímo odvodit byly již součástí ústavy z roku 1906.) Nadto doplňuje prvky odvozené z Chomejního konceptu nad justicí, legislativou i exekutivou stojícího a lidem nevoleného nejvyššího vůdce $\mathrm{z}$ řad ulamá. Dále počítá s Radou dohlížitelů zkoumající a vetující přijímané zákony a kandidáty do prezidentských a parlamentních voleb, a to na základě jejich souladu s islámem [podle Bumbálek 2007]. ${ }^{21}$

Část duchovních se s tímto fungováním režimu neztotožňuje a patří k jeho nejsilnějším kritikům. Tvrdí například, že se klerici nemají do politiky vůbec zapojovat. Poukazují na to, že demokracie a islám jsou v souladu, přičemž vedení země má respektovat jen vưli lidu a duchovním proto v politice náleží maximálně jakýsi poradní hlas.

Jiný tábor představují prorežimní duchovní podporující Chomejního koncepci vlády. Patrně vůbec největší část ale tvoří ti, kdo zastávají apolitické postoje a celá diskuze jim připadá nezajímavá a irelevantní [srv. Bumbálek 2007]. ${ }^{22}$

Propracované kritické reflexe režimu se ozývají také z řad laiků. Prominentní pozici s mezinárodním renomé zastává Abdolkarím Sorúš. Podobně jako Chátamí uplatňuje hermeneutický přístup, když rozlišuje mezi svatým a neměnným islámem a jeho časově a kulturně vázaným, proměňujícím se, omezeným a vždy nedokonalým lidským poznáním. Kdo tvrdí, že jako jediný nejlépe pochopil islám a jeho důsledky pro organizaci společnosti, podle něj ho pouze trestuhodně zneužívá ke svým mocenským cílům a napomáhá jeho degeneraci potlačováním jeho ústředního etického rozměru [dle Kropáček 2003]. Někteří analytici se za této situace dokonce domnívají, že nastolení očividně neúspěšného náboženského režimu přispívá k sekularizaci společnosti [např. Roy 2004; Zakaria 2004], ačkoliv s takto vyhrocenou tezí by v tradici ukotvený Chátamí jistě nesouhlasil.

\section{Chomejní jako král-filozof a bída šíitského historicismu (Karl R. Popper)}

Jeden z nejdůležitějších a nejpřesvědčivějších argumentů tzv. zeleného hnutí zformovaného po posledních zmanipulovaných prezidentských volbách (v roce 2009) poukazuje na nemožnost bezpečně předem identifikovat statečného, morálního, erudovaného a vůdčími vlohami nadaného nejvyššího vůdce $z$ řad kléru, jemuž se má svěřit moc. Tedy vlastně na nemožnost splnit Chomejního klíčový požadavek vyzdvihnout do čela státu krále-filozofa. Obzvláště když takový osobnostní profil dle mnohých zbožných

21 Po revoluci došlo k politické krizi a paralýze státu. Rada dohlížitelů totiž neustále vetovala a vracela zákony přijímané liberálnějším parlamentem. Byl proto zřízena Rada pro určování zájmů režimu, mající rozsuzovat spory. Může rozhodnout, že není nutné aplikovat islámské právo, pokud je v rozporu se zájmy státu [Bumbálek 2007].

22 V neformálních diskuzích se často operuje s procentuálním vyjádřením 15 : 70 : 15 (loajální, apolitičtí a opoziční klerici). Přitom odhady rozložení sil mezi duchovními před islámskou revolucí byly velmi podobné. 
šíitů odpovídá všehovšudy jen čtrnácti smrtelníkům: Prorokovi, jeho dceři a dvanácti imámům. ${ }^{23}$

Chomejního koncepce vůdcovství se přitom zřetelně podobá Platónově pojetí státu, vlády a krále-filozofa, vlastníka jediné pravdy a jakéhosi totalitárního poloboha vyvýšeného nad ostatní. ${ }^{24}$ Chomejní totiž klade sugestivně důraz na otázku „Kdo by měl státu vládnout? “, což nutně navozuje odpověd”, že ti nejlepší, nejmoudřejší a nejspravedlivější. Činí tak na úkor jiné otázky „Jak můžeme uspořádat instituce, aby neschopní vládcové nemohli způsobit př́liš mnoho škody?“ Karl Popper [1994] tvrdí, že toto uvažování je důsledkem idealizované představy mudrce a zvyku nekriticky uctívat velké osobnosti (viz existence kultu osobnosti v dnešním Íránu). V historii to pravidelně ústí v nesvobodu a rozbujení iracionality $\mathrm{v}$ životě společnosti. Zároveň jde o snahu obejít složitou problematiku vlády institucí jednoduchým a čistě personálním řešením, které v určité myšlenkové zkratce předpokládá, že blaho státu a společnosti je postaveno především na osobních kvalitách vůdce.

Popper tedy rozlišuje tyranii, kde je změna vlády možná pouze skrze revoluci, a demokracii, jejímž hlavním cílem je tyranii zabránit. V demokracii je proto vždy ponechána možnost institucionalizované, nenásilné a nerevoluční změny vlády ze strany ovládaných (dle principu „připravit se na nejhorší, ale usilovat o nejlepší“). Politika demokratické vlády může být často méně moudrá než v případě tyranie, avšak dá se vždy změnit k lepšímu, což je její hlavní deviza. Naprostá většina vládců v historii totiž byla podprůměrná - mravně i intelektuálně, a to podle kritiků stále více vystihuje situaci v Íránu. ${ }^{25}$

Lze uvést tezi, že korumpuje-li moc, absolutní moc korumpuje absolutně. Nelze se ani slepě spoléhat na to, že tyto tlaky spojené s mocí jakkoliv původně morální vládci dlouhodobě zvládnou. Konečně spolu se Sókratem lze proti koncepci vládce-filozofa v Chomejního pojetí upozornit i na její vážné morální slabiny. Je správné, vládnou-li moudří, kteří si uvědomují, jak málo toho ve skutečnosti vědí, jak obtížné je dosáhnout pravého poznání nebo spravedlnosti. Jde o autority, které znají vlastní omezení, nejsou pyšné, opojené mocí a nedomnívají se, že monopolně vlastní pravdu, kterou však nikdy nepřestanou hledat a milovat. Oproti tomu Platón i Chomejní chápou vzdělání především jako bariéru mezi vládci a ovládanými, jako ospravedlnění maximalizace moci. Vrstva islámských právníků v čele s nejvyšším vůdcem rekrutujícím se z jejich řad má vládnout prostě proto, že jako jediní disponují specializovaným věděním, a tak ze všech nejlépe řemeslu moci rozumí. $Z$ těchto důvodů se jim má plně důvěřovat a do vlády pokud možno nemluvit, jak lze dovodit ze zásady, že erudice v islámském právu je ústavním požadavkem pro zastávání funkcí ve státním aparátu [srv. Popper 1994].

Chomejního a provládní kliku oficiálních ulamá lze navíc spolu s Popperem popsat jako partu profesionálních proroků, kteří díky svému vědění a moudrosti - a s pomocí šíitských eschatologických vizí - „poznali“ a pochopili nevyhnutelné zákony dějin.

23 E-mailová komunikace s příznivci Zeleného hnutí, srpen, 2009-červen, 2010.

24 Vycházím ale hlavně z kritické a nikoliv všeobecně přijímané interpretace Platóna z pera Karla R. Poppera [1994].

25 Chámeneí nedisponuje dostatečnou odbornou erudicí, nepatří k velkým ajatoláhům jako Chomejní. Také na adresu elitních režimních duchovních zaznívá z řad obyvatel obvinění z pokrytectví: „Kritizují korupci, ale jsou nejzkorumpovanější, káží proti alkoholu, ale pijí nejlepší víno, vyzdvihují skromnost, ale žijí v luxusu, horují za sexuální zdrženlivost, ale obveselují se s prostitutkami. “ Rozhovor autora studie s mladými Íránci. Isfahán, červenec, 2007). 
Umí tak přesvědčivě vyložit minulost, současnost i budoucnost. S pomocí proroctví mobilizují lid ke svým cílům a dále legitimizují svou moc, přičemž neutralizují akceschopnost oponentů, kteří jsou tak jen zoufalci jdoucí proti železným zákonům dějin. Také v podání šítského historicismu jsou totiž dějiny pevně sevřeny zákony, nikoliv však př́rodními (přirozený výběr v boji o přežití a vítězství nadřazené rasy) nebo ekonomickými (tř́ídní boj jako motor dějin) jako $\mathrm{v}$ případě sekulárních ideologií, nýbrž náboženské povahy. Šíité jsou Prorokem a Bohem vyvoleným společenstvím, jako „strana Alího“ jsou oprávněni stát $\mathrm{v}$ čele muslimské obce a patří jim budoucnost (zvláštní postavení šíitů v dějinách však postuluje také Mohammad Chátamí). Božské zákony v souladu s šíitskou eschatologickou vizí slibují návrat skrývajícího se imáma. Dříve či později tak zařídí, že bude spravedlnosti učiněno zadost. Již dnes se však zbožní věřící mají s vědomým vlastní výjimečnosti a historické mise postavit na stranu dobra v boji proti zlu a podporovat islámskou republiku v duchu sedmého pilíre šíitské víry, který explicitně přikazuje prosazovat dobré a zabraňovat zavrženíhodnému.

Tento historicismus se ale stejně jako v případě dalších ideologií (dle Poppera Platónem počínaje a marxismem, rasismem nebo nacismem zdaleka nekonče) paradoxně snoubí se sociálním inženýrstvím: člověk je minimálně částečně pánem svého osudu a lidé mohou s přihlédnutím k poznaným dějinným zákonům efektivně formovat vlastní historii. Také Chomejní horuje pro vytvoření ideálního státu na troskách předchozího „neřádu“ svrženého a kompletně rozbořeného revolucí. Stát, který má přinést Ráj na Zemi, musí být silný a centralizovaný, aby dokázal prosadit radikální přestavbu celé společnosti, vnutil lidem tu pravou islámskou morálku, vyrobil nové ctnostné občany ${ }^{26}$ a přinesl štěstí i do toho nejzapadlejšího koutu Persie. Ačkoliv šíité hledí do budoucnosti s optimismem a s nadějemi v návrat skrytého imáma, utopický model ideální organizace společnosti, státu a politických záležitostí Chomejní odvozuje především ze štastného „zlatého věku“, kterým byla vláda proroka Mohammeda a dědičných imámů. (Platón viděl předobraz své utopie pro změnu ve starověké Spartě a Krétě.) Změnám vedoucím k mravnímu a poté i politickému úpadku, k chaosu, ztrátě pravidel a orientace v rychle pulzujícím světě (jak ukázala situace v době sekulární diktatury šáha), lze zabránit příchodem moudrého vůdce a nastolením islámského státu. Jeho idealizovanou předlohu lze nalézt $\mathrm{v}$ prapočátcích muslimské obce. Jakákoliv změna tohoto revolučně nastoleného ideálního „zastaveného státu“ je pak vždy jen změnou k horšímu. Proto není radno ho kritizovat, pokoušet se o dílčí reformy či dokonce revoluční přeměnu.

K dosažení dlouhodobé stability, zakonzervování změny a uchování mocenského statu quo je dle Platóna zapotřebí bezostyšně zkonstruovat takové náboženství, jež si vynutí poslušnost díky strachu z porušování režimem ustavených pravidel. Lidé musí věrit, že bohové vše sledují, nikomu nic nedarují a jsou to také oni, kdo bez slitování trestají přestupníky, opozičníky a různé devianty. Vytvoření lživého mýtu či falešného náboženství, slouží-li společenské soudržnosti, dobru celku a moci „ctnostného“ státu, je v nej-

26 Jak naznačuje existence mravnostní policie, postup vǔči homosexuálům a alkoholu, potírání „západní“ kultury (např. donedávna se nesměly pro „nemorálnost“ dovážet kytary) a klíčová role náboženské výchovy. Popper prožretelně argumentuje, že státní péče o morálku občanů skrze vymýšlení, prosazování a kontrolu dodržování př́sných norem vede k opačnému efektu, ke zničení smyslu pro individuální zodpovědnost. Mravnost státu je navíc vždy nižší než mravnost průměrného občana, proto by měli občané kontrolovat chování státu, ne naopak. 
lepším pořádku. Náboženství je tedy zapotřebí pragmaticky politicky vytěžit, bezbožnost je pak nutné v praxi pronásledovat. Chomejního monoteistický politický koncept je v tomto ohledu analogický, šíitský islám redukuje na jeho politickou dimenzi, přičemž prosazuje pouze jednu z mnoha možných interpretací islámského státu (jak ukazuje legitimizace moci ideologií odvozenou z šíitského náboženství, lustrování volebních kandidátů i přijímaných zákonů dle souladu s Boží vůlí, pronásledování „nevěřících“ báhaistů a přísné tresty ospravedlňované islámským právem). Kromě „povýšené lži“ je také zapotřebí pěstovat kolektivismus, ve kterém se jedinec navždy podřídí zájmům celku, a usilovat o posílení stability státu [srv. Popper 1994]. ${ }^{27}$

\section{Velká syntéza Východu a Západu a globální občanská společnost (Amitai Etzioni)}

Přínos Chátamího navzdory jeho íránocentrismu spočívá v tom, že obohacuje a konfrontuje dominantní výklady světa po konci studené války, nabízené západními autory. Mezi nimi zaujímají prominentní místo Samuel Huntington (střet civilizací) a Francis Fukuyama (konec dějin). S Fukuyamou se Chátamí shodne na představě pokroku a zejména na metodologickém východisku, že motorem dějin je univerzální lidská přirozenost. Zatímco se ale dle Fukuyamy cesty vývoje jednotlivých společností sejdou na „konečné“ v podobě liberálně-demokratické kapitalistické společnosti západního střihu, dle Chátamího jsou dějiny nakloněny islámskému revolučnímu modelu [srv. Fukuyama 2002; Chátamí 2001]. Styčným bodem s Huntingtonem jsou jeho úvahy v dimenzích civilizací (ty ale Huntington líčí jako uzavřené, homogenní a statické) a zejména identifikovaná rostoucí role náboženství v politickém životě. S tím souvisí náboženské obavy z možného nedorozumění různých kultur a zrychlení dialogu. Společný je jim také aktivistický a esejistický styl provázený nedbalým definováním pojmů.

Zatímco Francis Fukuyama [2002] či Fareed Zakaria [2004] chápou západní hodnoty podpírající liberální demokracii a kapitalismu jako celosvětově univerzální, ${ }^{28}$ Samuel Huntington [1993, 2001, 2005] či Bernard Lewis [1990] se domnívají, že hodnotové systémy jednotlivých civilizací - a speciálně islámu - jsou neslučitelné se Západem. Zde vzývaný komplex hodnot individualismu, vlády zákona, pluralismu a svobody, zastupitelské demokracie či oddělení duchovní a světské autority údajně nerezonují ve zbytku světa a už vůbec ne mezi muslimy. Vzájemné hodnotové obohacování tedy podle jedněch není možné, podle druhých $\mathrm{k}$ němu vlastně není důvod, protože nezápadní části světa nemají co nabídnout a budou se jednostranně připodobňovat Západu.

Podle guru komunitarismu Amitaie Etzioniho [2004] ale ani jeden přístup nepočítá s tím, k čemu v reálném globalizovaném světě stále dochází, ani s tím, co je dle jeho normativní koncepce „dobré společnosti“ žádoucí, ke vzájemnému, obousměrnému

27 Uved’me, že z dostupné literatury není autorovi těchto řádek známo, nakolik a zda vůbec Chomejní - přímo či nepřímo - navazuje na antického guru Platóna chápaného v jeho přísné popperovské interpretaci jako předchůdce všech pozdějších totalitárních ideologů uzavřené společnosti. Existuje ale až příliš mnoho styčných míst, aby šlo pouze o náhodu. Tuto inspiraci by bylo možné vysvětlit vlivem antické kultury na formování a rozkvět islámského světa. Inspirace, narážky a odkazy na antiku lze ostatně vyčíst i z textů Mohammada Chátamího.

28 Prvním moderním teoretikem konce dějin je údajně T. H. Marshall s tezí odvozenou z vývoje Anglie, hovořící o historickém směřování od autoritářství a feudalismu k demokracii. Nejprve se prosadí občanská práva - rovnost před zákonem, pak práva politická - rovné hlasovací právo a konečně práva sociální [Etzioni 2004: 168]. 
hodnotovému obohacování a vytváření globální hodnotové syntézy, která má vyústit v definování sady celému světu společných základních hodnot. Jeho pojetí dialogu civilizací a nového globálního mezinárodního řádu přitom silně připomíná koncepci Mohammada Chátamího.

Západ se dle této diagnózy potýká s vyhroceným individualismem (anomie a deviace, morální vakuum, úbytek sociálního kapitálu), Východ pak trpí „autoritářským komunitarismem“ (potlačení lidských práv, občanských a ekonomických svobod). Západ a Východ totiž dosud představují dva extrémy zdůrazňující prŕliš jednostranné a vzájemně protichůdné sady hodnot: za prvé důraz na práva jedince vs. důraz na závazky a povinnosti vůči společenství; za druhé důraz na autonomii a hodnotu jedince vs. důraz na sociální řád, společenský soulad a harmonii; za třetí důraz na svobodnou volbu vs. důraz na podřízení se autoritě (starším, nadřízeným aj.); za čtvrté důraz na sekularismus a hodnotový relativismus vs. zdůraznění transcendentna a klíčových hodnot; za páté př́lišný historický optimismus až triumfalismus a aktivní přitakání rychlým změnám vs. cynismus až fatalismus [tamtéž: 15, 50].

K odstranění nedostatků Východu a Západu, posílení jejich silných stránek a dosažení „dobré společnosti“ - autor věří, že lze kombinovat výhody vřelé a bezpečné pospolitosti (Gemeinschaft) i individualizované a dynamické společnosti (Gesellschaft) - je dnes nutná rovnováha mezi západním a východním hodnotovým systémem, jakási „zlatá střední cesta“. Této cesty lze dosáhnout právě dialogem civilizací, chápaným jako hodnotové syntézy či konvergence Západu a Východu, za kterou autor pléduje spolu s Mohammadem Chátamím. K dosažení „dobré společnosti“ je však kromě dialogu zapotřebí vybojovat také řadu konfliktů odehrávajících se v celosvětovém měřítku. Nejde přitom ale o zásadní spor mezi jednotlivými civilizacemi, ale o konflikt uvnitř každé z nich: o střet „měkkého" (soft) a "tvrdého“ pojetí tradice a víry [podrobněji tamtéž: 83-90]. I v tomto bodě se Etzioni setkává s Chátamím, kterého lze chápat jako představitele „měkkého islámu“ (oproti nim Chomejní spadá do tábora islámu „tvrdého“).

\section{Rozmanité modernity a íránský politický islám včera, dnes a zítra (Shmuel Eisenstadt)} Také izraelský sociolog Shmuel Eisenstadt [2000] explicitně staví svou slavnou koncepci rozmanitých modernit do protikladu s dosud dominujícími výklady světa a jeho vývoje (modernizační teorie, konec dějin, střet civilizací). Modernita má podle autora pevné a neměnné univerzální jádro, ale velké množství geografických, kulturních a historických variant. Je vždy a všude spjata s určitou mírou strukturální diferenciace nejrůznějších institucí. Podobně lze identifikovat univerzální jádro kulturního programu modernity v podobě vědomí, že „společenský ráa může být aktivně formován vědomou a záměrnou lidskou činností“ [tamtéž: 5]. Kritický kulturní práh modernity tedy souvisí s určitým „odkouzlením světa“ a představou, že sociální svět není jednou pro vždy stvořen a dopředu naprogramován Bohem. Naopak stávající status quo lze změnit. Modernita dostala do vínku reflexivitu spjatou s možností nekončícího zpochybňování dosavadního řádu, jež ústí ve schopnost - jakkoliv limitovanou - neustálé sebekorekce moderních společností. Kromě důrazu na participaci členů společnosti na společném projektu modernity se rodí také moderní koncept autonomního a tradičními autoritami neomezovaného jednání orientovaného na budoucnost, jež je chápána jako sféra množství lákavých alternativ dosažitelných a realizovatelných právě aktivním jednáním a politickou participací. 
Ve skutečnosti však nepřetržitě vznikají nejrozmanitější institucionální a ideologické vzorce modernity, a to $\mathrm{v}$ různých společnostech a zároveň v různých fázích jejich vývoje. Výsledkem proto není globální institucionální homogenizace a hegemonie západního programu modernity. Shmuel N. Eisenstadt se snaží vysvětlit jak důvody vysoké variability konstelací a způsobů organizování jednotlivých diferencovaných institucionálních sfér, tak také téměř nekonečnou rozmanitost neustále předkládaných konkurenčních kulturních programů modernity. Rozmanité modernity jsou výsledkem dynamiky, v níž dochází k neustálému propojování, kombinaci a interakci univerzálních modernizačních trendů a partikulárních tradic, kulturních substrátů a historických zkušeností. Různé vzorce modernizace jsou dále výsledkem pozitivního či negativního vymezování vůči západní modernitě. Díky svému historickému prvenství modernita funguje jako referenční bod, jenž nelze ignorovat, vždy je nutné zaujmout k němu jasné stanovisko. Různé institucionální a ideologické verze modernity jsou též výsledkem střetů a konfliktů řady sociálních a politických hnutí prosazujících vlastní pojetí.

„Civilizace modernity“ tedy historicky začala v Evropě. Také dosud nedopsaný „př́iběh neustálé a kontinuální konstituce a rekonstituce rozmanitosti kulturních programů modernity“ [tamtéž: 2] má počátky právě zde, jak ukazují liberální a utopické verze sovětského či fašistického typu. S dalšími razantními výzvami pro „klasický věk modernity“ pak přicházejí tzv. nová sociální hnutí (ekologická, mírová, ženská, hnutí za práva menšin). Mezitím však již dochází k obrovskému nárůstu variability modernity v souvislosti s její geografickou expanzí. Evropský kolonialismus je spjat s šířením moderních institucí (např. byrokracie, soudy, národní stát, reprezentativní politika) daleko za hranice historicko-kulturního kontextu evropských společností, nejprve v Novém světě ${ }^{29}$ a v Asii (Indie, Japonsko), poté na Blízkém východě a nakonec v Africe.

Západní verze modernity je od té doby ve světě chápána ambivalentně. Často je viděna jako přitažlivá, zároveň ale dochází $\mathrm{k}$ „neprětržité selekci, reinterpretaci a reformulaci importovaných ideji“ [tamtéž: 15]. Výsledkem jsou neustálé programové inovace ústící v nejrozmanitější ideologické a institucionální vzorce modernity. V pozadí těchto procesů sociální transformace nestojí jen nezdolná aktivita soupeřících hnutí a jejich různých programů, nýbrž i vliv místně specifických tradic, hodnot a historické paměti včetně odlišných dopadů kolonialismu a trendů modernity (viz Japonsko či Indie se specifickou kombinací místních a západních prvků).

Nejnovějšími významnými „programátory“ modernity jsou v tomto příběhu vysoce zpolitizovaná náboženská hnutí celého světa, zejména světa islámu. Jde o součást širšího proudu tzv. nových náboženských hnutí jakožto vyzyvatelů „klasického věku“ modernity, jenž vykrystalizoval v Evropě v 19. a první polovině 20. století. Extrémní protizápadní a protiosvícenská fundamentalistická hnutí Eisenstadt chápe jako druhý výhonek totalitních ideologií jakobínského typu, která společně věří v primát politické moci jako nástroje radikální transformace člověka a celé společnosti. V tomto schématu lze dobře vykládat íránský revoluční fundamentalismus, ale také jeho vyzývatele v podobě reformního programu v podání Mohammada Chátamího. Také umírněná náboženská

29 Právě Spojené státy představují první radikální transformaci evropské modernity vzniklou vojenskou konfrontací a ideologickým vymezením vůči Evropě. Navíc se záhy sama chápe jako univerzální referenční bod modernity. 
politická hnutí se totiž uchylují ke konfrontaci se západním modelem, případně se snaží selektivně přebrat a přizpůsobit některé jeho prvky a interpretovat je v pojmech vlastní tradice: „(...) snahou je oddělit Západ od modernity, popř́ít západní monopol na modernitu a odmítnout západní kulturní program jako východisko modernity“ [tamtéž: 22]. Tím dochází ke změně vztahů Západu a nezápadních civilizací, ale také k proměnám vztahů mezi náboženstvím a společností. Dnešní globální svět lze podle autora popsat jako svět, ve kterém se dějiny nezastavily, ale probíhá neustálá reinterpretace kulturních programů modernity, na jejichž základě se rodí nejen různé „porozumění“ modernitě, ale také stále nové pokusy o konstrukci jejích nejrozmanitějších alternativních institucionálních forem.

Inspirován konceptem rozmanitých modernit a s odkazy na konkurenční programy Mohammada Chátamího a ajatoláha Chomejního rozpracovává a interpretuje vývoj Íránu zejména Masoud Kamali [2006, 2007]. ${ }^{30}$ Autor odmítá existenci jednolitého islámského světa, stejně i myšlenku jediné verze modernity a jedné kontinuitní cesty k ní: „(...) muslimské společnosti a jejich moderní historie jsou tak rozdílné a různorodé jako v případě jiných společností“ [Kamali 2007: 378]. V Egyptě například přišel sultán Muhammad Ali s razantní modernizací armády a vzdělávání, což bylo zcela něco jiného ve srovnání s pozdějším arabským socialismem Násira. Modernizační projekty v podání vojensky upadající Osmanské říše a pozdějších kemalistů v éře Turecké republiky jsou také zcela odlišné a diskontinuitní. V samotném Íránu pak lze odlišit hned čtyři radikálně rozdílné a po sobě jdoucí modernizační programy. Doplňují je dvě revoluce (1906 a 1979), chápané jako prudké reakce náboženských a tradičně dominantních skupin, jež se domnívaly, že na dosavadní modernizaci nevydělaly.

Perská modernizace za dynastie Kadžárovců byla zahájena v reakci na „trauma porážky“" po konfrontaci tisícileté říše s dosud přehlíženou Evropou (Anglie, Rusko). Moderní svět se tak v Íránu nejprve v plné kráse představil skrze válku a soupeřivou mezinárodní politiku. Jasným cílem programu Nového řádu (Nezam-e jadid) bylo zefektivnění armády a státní byrokracie. Jako v případě všech následujících modernizačních programů, i zde docházelo k selektivní inspiraci Západem, ke „kombinaci různých [západních] myšlenek a [západních] organizačních forem“ [tamtéž: 374]. Iniciátorem změn přitom byla úzká a od společnosti odtržená elita, které chyběla jakákoliv společenská podpora. Selektivní modernizační program, jenž sledoval pouze její zájmy a její porozumění modernitě, se tak musel prosazovat silou (armáda, tajná policie), protože naopak nechyběla sílící opozice vůči novotám. Změny podkopávaly postavení dosavadních

30 S ohledem na muslimské země nabízí pohled inspirovaný koncepcí různorodých modernit i John Gray [2005]. Do začátku novověku byly veškeré utopie situovány do neobjevených a vzdálených končin - „budoucnost ještě nebyla vynalezena“. Ideu pokroku Evropa objevila, když došlo k souběhu růstu vědění, bohatství a snad i štěstí. Jde o sekularizovanou představu křestanské spásy na tomto světě. Je univerzálně dostupná všem, ale skrze jedinou správnou cestu, víru a životní styl. Odtud pramení netolerantnost jinakosti monoteistických náboženství (oproti polyteizmu) i modernizačních programů samých v jejich liberální, komunistické, nacistické a islamistické verzi. Domnívají se, že ztělesňují jedinou správnou cestu k budoucnosti. Radikální islamismus kombinuje islámskou tradici a západní ideologie a technologie. Podobně jako ruští anarchisté 19. století věří, že lepší zítřky lze vybudovat skrze okázalou destrukci stávajícího řádu. Nejúspěšnější jsou ale ty nezápadní modernizační programy, jež se snaží maximálně opatrně a selektivně roubovat západní prvky a technologie do místního kulturně-sociálního kontextu (např. v Japonsku, Číně, Indii; Turecko budiž výjimkou). Přitom se vždy více řídí tradicí než slepým přijímáním západních předloh. Existuje pak více způsobů, jak být moderní; modernizace nemusí být provázena individualizací, sekularizací, demokratizací. 
tradičních spojenců státní moci, duchovních, obchodníků bazaru a královského dvora. Vadila jim také nákladnost reforem, vedoucí k ekonomické závislosti na západních mocnostech a firmách, jimž byly udělovány monopolní koncese v daných hospodářských odvětvích. Tradiční ekonomické vrstvy tak přicházely na mizinu. Byly to právě obchodníci a ulamá, kdo se postavily do čela ústavní revoluce (1905-1909) a zmobilizovaly pro ni podporu. Pokus o ústavní modernizaci přitom sledoval modernizaci politického systému. To mělo umožnit, aby lidé mohli do prováděných reforem, jež se jich stále více každodenně dotýkaly, zasahovat.

Po 1. světové válce došlo k totálnímu politicko-ekonomickému kolapsu státu. Na jeho troskách se $\mathrm{k}$ moci vyšvihla dynastie Pahlaví s programem autoritářské a vysoce selektivní modernizace. Inspirací modernizačního programu se stala nastupující „nová Evropa“, zejména fašistické Německo a Itálie. Šáhovi zde imponovala národní jednota, korporativismus, vláda jedné strany a dokonalá centralizace moci jako předpoklad revoluční proměny celé společnosti. Navíc „nová Evropa“ byla přirozeným spojencem proti koloniální „Evropě staré“. Později se režim selektivně obracel pro inspiraci k USA a docházelo k překotnému kulturnímu „pozápadňování“. Ambicí nebylo nic menšího, než vytvořit silný centralizovaný národní stát, nejsilnější zemi Blízkého východu, dominující Perskému zálivu a vyvažující moc Indie v Indickém oceánu [srv. Richards - Waterbury 2008]. Předpokladem prosazení masivní modernizace se stala stabilizace a konsolidace moci, přičemž šáh postupně zlikvidoval veškerou opozici. Jestliže byla nejprve pod dojmem resuscitace zkolabovaného státu diktatura chápána jako hotové požehnání, postupně sílila kritika. Z politiky byly nakonec vyloučeni všichni - radikálové i umírnění, tradiční vrstvy i zástupci nově se rodící občanské společnosti, islamisté, sekulární levice a liberálové. Zničilo to dlouholetou rovnováhu a vzájemné vyvažování jednotlivých skupin. Režim tak byl rostoucí měrou závislý na vnější podpoře ze strany Západu.

Modernizační program šáha si znepřátelil tradiční i nastupující vrstvy, což nakonec vedlo k revoluci (1979). Islamistická éra ale přinesla novou formu diktatury a autoritářské modernizace. I přes snahu zlikvidovat veškerou opozici a tradiční i prozápadní občanskou společnost dochází po válce s Irákem (1988) a smrti Chomejního (1989) k její obrodě. Právě doba prezidentování Chátamího (1997-2005) signalizuje narůstající konflikt modernizačních programů liberálnějších reformistů a náboženských monopolistů. Ti však zatím vítězí. Kromě teroru konzervativců spatřuje Kamali hlavní příčinu v rozkolu uvnitř občanské společnosti. Její dva tábory, kvazi-tradiční, jenž nechápe islám v rozporu s modernitou a demokracií stejně jako křestansko-demokratické strany a hnutí v Evropě a hybridní „pozápadnělá“ usilující o úplnou sekularizaci a oddělení náboženství a politiky, musí spolupracovat, jinak se demokratizace zpomalí jako na celém Blízkém východě [Kamali 2007].

\section{Chátamí jako hvězda západních intelektuálů}

Chátamího lze pokládat za „náboženského intelektuála“, především s ohledem na jeho koncept „nového“ člověka, jenž se má zrodit po reformě íránského školství, spočívající v propojení náboženských seminářů a západních sekulárních univerzit [bliže Chátamí 2001: 79].

Pro dialog mezi civilizacemi je autor vybaven nejen po stránce znalostí reálií islámské civilizace, nýbrž i Západu. Humanistická perspektiva, včetně silného pocitu 
globality - Chátamí uvádí, že „lidé žijící v dnešním světě se nalézají na palubě téže lodi“ (tamtéž: 23), je pro část západních intelektuálů atraktivní, jak naznačuje postoj amerického islamologa Johna Esposita a sociologa Amitaie Etzioni. Chátamí používá a propaguje navíc západní koncepty, i když jim často dává vlastní obsah. Kosmopolitní nadhled ale Chátamí kombinuje s etnocentrickou perspektivou živenou perským patriotismem zdůrazňujícím íránské unikáty a specifika a ústící až v perský mesianismus. ${ }^{31}$

Chátamí se jako prezident v souladu se svou koncepcí zasadil o změnu zahraniční politiky [Gombár 2001], ,32 čímž se zařadil k významným propagátorům mezikulturního dialogu, jakými jsou např. malajský vicepremiér Anwar Ibrahim či prezident Indonésie Abdurrahman Wahid [srv. Esposito 2003: 135-139]. Nelze se ale vyhnout dojmu, že šlo o pragmatický tah: pokud nemůžeme revoluci šírit zbraněmi, budeme tak činit skrze dialog, $v$ němž se naše pojetí ukáže jako nejpřitažlivější. Kritici z řad amerických neokonzervativců [např. Rubin 2008] Chátamímu též vyčítají, že neprosadil žádnou reformu, ve finále tak jen legitimizoval systém [srv. Bumbálek 2007]. Navíc se líbivými řečmi o dialogu uchlácholila ostražitost Západu a Írán nerušeně pracoval na jaderném programu [Cirincione 2008; Šlachta a kol. 2007].

Koncepci Mohammada Chátamího lze považovat za program selektivní modernizace, zasazený do širších historických souvislostí, ve kterém hraje vưdčí roli občanská společnost a také dialog s ostatními civilizacemi, především se Západem, jenž má vést k opatrné a rozvážné hodnotové syntéze toho nejlepšího z obou kulturních okruhů a mezinárodní kooperaci při řešení globálních problémů. Oproti tomu autoritářský modernizační program ajatoláha Chomejního představuje konkurenční vizi v rámci šíitského islamismu, jenž se chce ke štastným zítřkům, sociální spravedlnosti a morální transformaci společnosti dopracovat skrze vládu moudrých duchovních. K vnějšímu světu se pak staví s ohledem na historickou zkušenost přinejmenším podezíravě. Konflikt těchto dvou typů modernizačních programů prezentovaných dvěma tábory šíitského politického islámu pak určuje dynamiku íránské společnosti. Přitom oba programy jsou značně vágní a „mlhavé“.

Vývoj v Íránu je součástí širšího trendu „vyjednávání“ podoby modernity v nezápadních post-koloniálních či post-socialistických společnostech. Mark Juergensmeyer [1994, 2008] ukazuje, že v porevolučním Íránu, stejně jako v téměř celém mimoevropském světě, dochází k pokusu nahradit dosud dominující, avšak neúspěšný a zdiskreditovaný sekulární nacionalismus nacionalismem náboženským. Toto snažení je chápáno jako završení národní emancipace a dekolonizace. Podobně se vyjadřuje též ruský sociolog Alexandr Panarin [2003], když hovoří o nové revoluci vědomí v tzv. druhém a třetím světě. Zde nejprve převážila snaha zcela odhodit vlastní kulturu a zařadit se co nejrychleji do klubu západní prosperity, což se však po několika dekádách ukázalo jako totálně neúspěšná strategie. Reakcí je obrat ke kultuře a kořenům. Kultura se chápe jako zdroj důstojnosti a pozitivní identity, ale zejména jako základ vlastní verze, interpretace a osvojení modernity. Ideu modernity je podle něj nutno bránit, reformovat a obrodit

31 Revoluční Írán může být podle této představy považován za nejlepší model, Íránci za nejlepší osobnostní typy propojující pozitiva Východu i Západu.

32 Madeleine Albrightová se v roce 2000 Íráncům oficiálně omluvila za dlouhodobé zasahování do vnitřních záležitostí a za účast USA na odstranění demokraticky zvoleného premiéra Mossadequa v roce 1953 [Gombár 2001]. 
s pomocí „východní inspirace“: „Pravá inteligence má dnes své srdce na Východě a rozum na Západě“ [tamtéž: 356]. Koneckonců v souvislosti s nutností mezináboženského dialogu hovoří o potřebě korigovat současnou jednostrannou verzi západní modernity také český islamolog Luboš Kropáček [1996, 1999]. 


\section{Literatura}

Afary, Janet - Anderson, Kevin. [2005]. Foucault and the Iranian Revolution. Gender and the Seductions of Islamism. Chicago: The University of Chicago Press.

Arjmand, Reza - Daun, Holger. [2005]. Islamic Education. In. Zajda, Joseph. International Handbook on Globalisation, Education and Policy Research. Global Pedagogies and Policies. Dordrecht: Netherlands/Springer, s. 377-388.

Brzezinski, Zbigniew. [1999]. Velká šachovnice. Praha: Mladá fronta.

Bumbálek, Cyril. [2007]. Politický islám v šíitském islámu a v Íránu. In. Souleimanov, Emil (ed.). Politický islám. Praha: Eurolex Bohemia, s. 112-147.

Buruma, Ian - Margalit, Avishai. [2005]. Okcidentalismus. Západ očima neprátel. Praha: Lidové noviny.

Cvrkal, Zdeněk. [2007]. Írán. Praha: Libri.

CMIP [2006]. The attitudes to „the other" and to peace in Iranian school books and teachers guides Institute for Monitoring Peace and Culture Tolerance in School Education. Dostupné na < http://www.impact-se.org/research/iran/index.html > [12. 9. 2009].

Cirincione, Joseph. [2008]. A Mideast Nuclear Chain Reaction? Current History 107 (December 2008), No. 713, s. 439-442.

Čejka, Marek. [2009]. Írán mezi osami zla a dobra. MF Dnes (Kavárna), 14. 3. 2009, s. D7

Dekmejian, Hrair. [1995]. Islam in Revolution. Syracuse: Syracuse University Press.

Eisenstadt, Shmuel. [2000] Multiple Modernities. Daedalus 129 (Winter 2000), No. 1, s. 1-29.

Esposito, John. [2003]. Unholly War. Terror in the Name of Islam. New York: Oxford University Press.

Etzioni, Amitai. [2004]. From Empire to Community. A New Approach to International Relations. New York: Palgrave Macmillan.

Freedom House [2008]. Discrimination and Intolerance in Iran's Textbooks. Freedom House, Special Report [online]. dostupné na Freedom House.org., http://www.freedomhouse.org/ template.cfm? page $=383 \&$ report $=60$ [12. 9. 2009]

Fukuyama, Francis. [2002]. Konec dějin a poslední člověk. Praha: Rybka Publishers.

Gombár, Eduard. [2001]. Dramatický půlměsíc. Sýrie, Libye a Írán v procesu transformace. Praha: Karolinum.

Gray, John [2004]. Al Kajda. A co to znamená být moderní. Praha: Mladá fronta.

Huntington, Samuel. [1993]. The Clash of Civilizations? Foreign Affairs 72 (Summer 1993), No. 3, s. 22-49.

Huntington, Samuel. [2001]. Střet civilizací. Praha: Rybka Publishers.

Huntington, Samuel. [2005]. Kam kráčíš, Ameriko? Praha: Rybka Publishers.

Chátamí, Mohamed. [2001]. Islám, dialog a občanská společnost. Praha: Velvyslanectví Íránské islámské republiky.

Chomejní, Rúholláh. [2004]. Velájat-e Faqíh. Islámská vláda. Teherán: Institut pro uspořádání a vydávání děl Imáma Chomejního (Oddělení mezinárodních vztahů).

Chomsky, Noam. [2003]. 11. 9. Praha: Mezera.

Inglehart, Ronald - Norris, Pipa. [2004]. Sacred and Secular. Religion and Politics Worldwide. Cambridge: Cambridge University Press.

Inglehart, Ronald - Welzel, Christian. [2006]. Modernization, Cultural Change, and Democracy. The Human Development Sequence. Cambridge: Cambridge University Press.

Juergensmeyer, Mark. [1994]. The New Cold War? Religious Nationalism Confronts the Secular State. Berkeley: University of California Press.

Juergensmeyer, Mark. [2008]. Global Rebellion. Religious Chalenges to the Secular State. Berkeley: University of California Press.

Kamali, Masood. [2007]. Multiple Modernities and Islamism in Iran. Social Compass 54 (Autumn 2007), No. 3, s. 373-387.

Kepel, Gilles. [1996]. Boží pomsta. Křestaná, židé a muslimové znovu dobývají svět. Brno: Atlantis. 
Kepel, Gilles. [2002]. Jihad. The Trail of Political Islam. Cambridge: Harvard University Press.

Klare, Michael. [2004]. Blood and Oil. New York: Metropolitan Books.

Kropáček, Luboš. [1996]. Islámský fundamentalismus. Praha: Vyšehrad.

Kropáček, Luboš. [1999]. Blízký východ na prelomu tisíciletí. Praha: Vyšehrad.

Kropáček, Luboš. [2002]. Islám a Západ. Historická pamět a současná krize. Praha: Vyšehrad.

Kropáček, Luboš. [2008]. Islám jako náboženství a jako civilizace. Kolokvium Religionistika a civilizacionistika, 22.-23. května 2008, Fakulta humanitních studií Univerzity Karlovy.

Lewis, Bernard. [1990]. The Roots of Muslim Rage: Why So Many Muslims Deeply Resent the West and Why Their Bitterness Will Not Be Easily Mollified. The Atlantic Monthly 226 (September 1990), No. 3, s. 47-60.

Lewis, Bernard. [2003]. Kde se stala chyba? Praha: Volvox Globator.

Moaddel, Mansoor. [2006]. Shia Islamic Societies. In Juergensmeyer, M. (ed.). The Oxford Handbook of Global Religions. Oxford: Oxford University Press, s. 447-456.

Nafisi, Rasool. [2007]. Iranian succession and the IRGC. Islamic Affairs Analyst, October, 2007, s. 5-7.

Panarin, Alexander. [2003]. Iskušenije globalizmom. Moskva: Algoritm.

Popper, Karl. [1994]. Otevřená společnost a její neprátelé I. Uhranutí Platonem. Praha: ISE.

Richards, Alan - Waterbury, John. [2008]. A Political Economy of the Middle East. Boulder: Westview Press.

Roy, Olivier. [1992]. The Failure of Political Islam. Cambridge: Harvard University Press.

Roy, Olivier. [2004]. Globalized Islam. The Search for a New Ummah. New York: Columbia University Press.

Rubin, Michael. [2008]. Iran's Global Ambition. AEI Middle Eastern Outlook, 17. 3. 2008, s. 5-10.

Rypka, Jan. [1946]. Íránský poutník. Praha: Družstevní práce.

Said, Edward. [2008]. Orientalismus. Západní koncepce Orientu. Praha: Paseka.

Sariolghalam, Mahmood. [2008]. Iran in Search of Itself. Current History 107 (December 2008), No. 713 , s. $425-432$.

Satrapi, Mariam. [2006, 2007]. Persepolis 1 a 2. Praha: BB/art.

Starrett, Gregory - Doumato, Eleonor. [2007]. Teaching Islam: Textbooks and Religion in the Middle East. Berkeley: Lynne Rienner Publisher.

Šlachta, Mojmír. [2007]. Ohniska napětí ve světě. Praha: Kartografie.

Tureček, Břetislav. [2007]. Světla a stíny islámu. Drama Blizkého východu a sonda do duší jeho obyvatel. Praha: Knižní klub.

Tureček, Břetislav. [2009]. Mezi zelenými zachránci Íránu. Respekt, č. 25, (8. červen, 2009), s. 32-33.

Zakaria, Fareed. [2004]. Budoucnost svobody. O krizi demokracie. Praha: Academia.

Zubaida, Sami. [2009]. Islam, the People and the State. London: I. B. Tauris.

Karel Černý (1980) pracuje jako vědecký pracovník na Pedagogické fakultě Univerzity Karlovy a zároveň je doktorandem na katedře sociologie Filozofické fakulty Univerzity Karlovy. Zabývá se empirickými výzkumy v oblasti vzdělávání, sociologickou teorii a problematikou současného Blízkého východu. Absolvoval studijní pobyt v Petrohradě (2005) a v Santa Barbaře (2010) a ziskal stipendium The German Marshall Fund of the United States (2009). 